\title{
Pollen-mediated Gene Flow from Coreopsis tinctoria to Coreopsis leavenworthii: Inheritance of Morphological Markers and Determination of Gene Flow Rates as Affected by Separation Distances
}

\author{
Sarah M. Smith ${ }^{1}$ and Zhanao Deng ${ }^{2}$ \\ University of Florida/IFAS, Department of Environmental Horticulture, Gulf Coast Research and \\ Education Center, 14625 County Road 672, Wimauma, FL 33598
}

\begin{abstract}
AdDitional INDEX wORDs. Asteraceae, interspecific hybridization, spotted ray flower, seed wing, trichome
Abstract. The genus Coreospsis is Florida's state wildflower. One species, Coreopsis leavenworthii, is nearly endemic to Florida and is highly desirable for use in highway beautification. Maintaining genetic integrity is critical for $C$. leavenworthii producers, growers, and users. Coreopsis tinctoria is closely related to and shares similar habitats with C. leavenworthii in Florida. Previous studies indicated that the two species could hybridize and the $F_{1}$ hybrids showed chromosomal aberrations and reduced pollen stainability. There has been strong concern that pollen-mediated gene flow from $C$. tinctoria could contaminate the gene pool and compromise the genetic integrity of $C$. leavenworthii. In the current study, hand pollination showed that $C$. leavenworthii and $C$. tinctoria were highly compatible. $F_{1}$ hybrids were fertile and readily produced $\mathrm{F}_{2}$ and $\mathrm{BC}_{1}$ individuals. Inheritance studies indicated that the maroon spot on the ray flower is controlled by a single dominant allele and is homozygous in $C$. tinctoria. This spot serves as a reliable, easy-toscore morphological marker to detect pollen-mediated gene flow from $C$. tinctoria to $C$. leavenworthii. Following a discontinuous design, gene flow studies were conducted under field conditions in central Florida over 2 years. The highest rate of pollen-mediated gene flow from $C$. tinctoria to $C$. leavenworthii was $4.2 \%$ and occurred when the two species were grown $1.5 \mathrm{~m}$ apart. Gene flow from $C$. tinctoria to $C$. leavenworthii under field conditions followed a leptokurtic curve. Based on the obtained regression equation, separating the two species by $60 \mathrm{~m}$ or more could lower the pollen-mediated gene flow from $C$. tinctoria to minimal levels and protect the genetic integrity of C. leavenworthii.
\end{abstract}

The concept of "planting natives" has become broadly accepted by our society and is often required by federal, state, or local laws or policy. Native plantings have become a common practice in many national/state parks and are increasingly common in highway roadside treatments (Rogers and Montalvo, 2004). Native flowers (forbs) are one group of native plants that have been frequently used. Many states have adopted native wildflower planting programs for highway beautification and revegetation. For example, the Texas Department of Transportation (TxDOT) recently purchased and sowed 18,000 to $27,000 \mathrm{~kg}$ of wildflower seeds per year and actively managed 323,742 ha of highway rights-of-way in Texas for wildflowers (Markwardt, 2005). Use of native wildflowers along roadsides has not only increased aesthetic values and attracted tourists, but also reduced maintenance costs, enhanced wildlife habitats and biodiversity, augmented soil erosion control, and suppressed noxious weeds (Bryant and Harper-Lore, 1997). Members of Asteraceae are among the native wildflowers commonly planted. More than one-fifth of the wildflowers in Texas belong to this family (TxDOT, 2011).

An important consideration in native planting is the need to maintain the genetic diversity and integrity of the selected plant

Received for publication 29 Feb. 2012. Accepted for publication 3 May 2012. We thank Dr. Jeff G. Norcini, Dr. David G. Clark, Joyce Jones, and Gail Bowman for assistance on this project and the Florida Wildflower Foundation, Inc. for financial support.

${ }^{1}$ Graduate student. This is part of a $\mathrm{PhD}$ dissertation.

${ }^{2}$ Corresponding author. E-mail: zdeng@ufl.edu. taxa during seed production and planting (Rogers, 2004; Rogers and Montalvo, 2004). This is critical for the successful establishment and performance as well as for the sustainability of the native plant taxa, particularly for those taxa that are narrowly distributed (Havens, 1998; Rogers and Montalvo, 2004).

When different but cross-compatible taxa are brought into close proximity for seed production or planting, interspecific pollen-mediated gene flow (PMGF) can occur (Ellstrand et al., 1999). This type of gene flow can lead to genetic contamination of the native wildflower seeds being produced. When the hybrids show reduced seed viability and/or plant fitness, the effects of such gene flow can result in poor establishment, performance, and/or sustainability of the transplanted materials. This type of gene flow may also disrupt native taxa's local adaptation and genetic structure that have developed during natural selection and evolution (Laikre et al., 2010). Certain rare native taxa have been driven by this type of gene flow to the point of extinction (Largiadèr, 2007). The potential negative impacts of interspecific PMGF on the genetic diversity and integrity of native taxa in large-scale production and transplanting is a major concern to native plant seed producers, growers, and users. Monitoring and preventing undesirable PMGF has become a very active research area in recent years.

The genus Coreopsis, a member of the family Asteraceae, is Florida's state wildflower. One species, Coreopsis leavenworthii, is widely distributed in Florida but has been reported only in two counties outside of Florida, thus it is nearly endemic 
to Florida [U.S. Department of Agriculture (USDA), 2011; Wunderlin and Hansen, 2004]. Its habitats include roadside ditches, wet pine flatwoods, and other moist disturbed sites, which are common along highways in Florida (Kabat et al., 2007). Plants of this species can form a dense flower cover over the foliage. These characteristics make C. leavenworthii desirable for use in highway beautification projects. Seeds of this species have been in high demand. Commercially produced seeds are expensive (up to $\$ 258 / \mathrm{kg}$ in 2006) and seeds costs for planting are high (\$2900 to $\$ 4300 / \mathrm{ha})$. The quality of $C$. leavenworthii seed, including their genetic diversity and integrity, is critical for wildflower growers who produce seeds and end users of this native wildflower.

Coreopsis tinctoria naturally occurs in all states of the United States except Alaska, Nevada, and Utah and has been recommended for highway beautification in several states. Seeds of $C$. tinctoria are commercially produced in a number of states, mainly Texas. Naturalized $C$. tinctoria populations have been observed in several counties in Florida where $C$. leavenworthii also exists. Both species belong to the Calliopsis section and are known to be outcrossing species that are insectpollinated (Clewell, 1985; Wunderlin, 1998). Parker (1973) showed that $C$. leavenworthii and $C$. tinctoria were crosscompatible after hand pollination. Their $F_{1}$ hybrids showed reduced pollen stainability when grown in a greenhouse. Meiotic chromosome configuration analyses suggested that the two taxa might have several structural differences, including reciprocal translocations, between their genomes (Smith, 1976). These studies raised concerns that naturalized or newly planted $C$. tinctoria may hybridize with $C$. leavenworthii and the resulting interspecific PMGF may compromise seed quality, plant fitness, and genetic integrity of C. leavenworthii. However, information is lacking for the rates of PMGF between $C$. tinctoria and $C$. leavenworthii under field conditions and the effectiveness of physical separation for minimizing undesirable PMGF.

The objectives of this study were to determine 1) the crosscompatibility between $C$. leavenworthii and $C$. tinctoria; 2) the inheritance of potential morphological markers for detecting PMGF from C. tinctoria to C. leavenworthii; and 3 ) the rates of PMGF from $C$. tinctoria and $C$. leavenworthii under field conditions and the effects of separation distances on reducing PMGF from C. tinctoria to C. leavenworthii.

\section{Materials and Methods}

Seed sources. Coresopsis leavenworthii (COLE) seeds were collected by N. Bissett from a natural population in the Reedy Creek Mitigation Bank in Polk County, FL. Coreopsis tinctoria (COTI) seeds were purchased from Wildseed Farms in Fredericksburg, TX.

Determining Cross-compatibility between $C$. LEAVENWORTHII AND C. TINCTORIa. Plants of the two species were grown in a greenhouse at the University of Florida (UF) Gulf Coast Research and Education Center (GCREC, Wimauma, FL) in plastic containers $(3.2 \mathrm{~L})$ filled with a commercial soilless mix [Vergrow Container Mix A (VCMA); Verlite Co., Tampa, FL] containing a controlled-release fertilizer (15N3.9P-10K; 5-6 months Osmocote; Scott's, Marysville, OH). Temperatures in a greenhouse were between 18.3 and $29.4{ }^{\circ} \mathrm{C}$ (night/day). Plants were grown under natural light and photoperiods. Flower heads were bagged at the bud stage
( $\approx 10 \mathrm{~d}$ before anthesis) with glassine bags $(2.5 \times 5.0 \mathrm{~cm})$. Pollen was collected by tapping the pollen-shedding flower heads into a plastic container $(13 \mathrm{~cm}$ diameter $\times 2.4 \mathrm{~cm}$ deep $)$. To pollinate bagged flower heads, the glassine bags were removed, the pollen was blown off of the flower head, and the exposed flower heads were rubbed against the available pollen inside the container. Pollinated flower heads were rebagged immediately and the bags were kept on until the seeds matured and were harvested. Cross types included intraspecific outcrossing within both species, reciprocal interspecific crosses, $\mathrm{F}_{1}$ self-pollination, $\mathrm{F}_{1}$ sib crosses, and backcrosses (Table 1). Seeds from each cross were counted, and seed production of each cross was statistically analyzed using PROC GLM and Tukey's W procedure in SAS (Version 9.3; SAS Institute, Cary, NC) for analysis of variance and significance of mean difference.

INHERITANCE STUDY OF MORPHOLOGICAL TRAITS. Our preliminary studies showed that COLE and COTI differ obviously in three morphological characters, trichomes on the leaf petioles, the maroon spot on the ray flowers (Fig. 1), and seed wingedness. Trichomes are absent on the petioles of COLE plants but present on the petioles of COTI plants. Seed wings are present on COLE seeds but absent on COTI seeds. The maroon spot is absent on COLE flowers but present on COTI flowers.

Four types of crosses were made as described previously to investigate the inheritance of these morphological traits. Parental plants were grown in a greenhouse in plastic containers and hand pollinations were performed as described previously. COLE and COTI intraspecific and interspecific crosses were made between 14 June and 10 Aug. 2007. Self and sib crosses of $\mathrm{F}_{1}$ hybrids and backcrosses were made in July and Aug. 2008.

Seeds from all crosses were germinated on the surface of VCMA in 532-mL plastic containers in a greenhouse under conditions described previously. Seedlings were transplanted and grown in 32-cell flats (148 mL cell volume; Speedling, Sun City, FL) filled with VCMA and fertilized with $15 \mathrm{~N}-3.9 \mathrm{P}-10 \mathrm{~K}$ Osmocote, 20N-8.7P-16.7K water-soluble fertilizer (Peter's; Scott's), or $15 \mathrm{~N}-13 \mathrm{P}-12.5 \mathrm{~K}$ water-soluble fertilizer (Plantex; Plant Products Co., Brampton, Ontario, Canada). Approximately $55 \mathrm{~d}$ after seed sowing, seedlings were transplanted to polyethylene-mulched ground beds at the UF-GCREC (lat. $27^{\circ} 45^{\prime} \mathrm{N}$, long. $82^{\circ} 13^{\prime} \mathrm{W}$, USDA cold hardiness zone 9b, American Horticultural Society heat zone 10). The soil was a mix of Myakka, Haplaquents, and St. Johns sand with $\approx 1 \%$ organic matter and $\mathrm{pH}$ of 6.1 to 6.5 . The raised beds were $20 \mathrm{~cm}$ high, $61 \mathrm{~cm}$ wide at the top, and $71 \mathrm{~cm}$ wide at the base and were fumigated with $67 \%$ methyl bromide: $33 \%$ chloropicrin at the rate of $197 \mathrm{~kg} \cdot \mathrm{ha}^{-1}$. Plants were spaced $30.5 \mathrm{~cm}$ apart in rows and $122 \mathrm{~cm}$ between rows. Plants were fertilized with a total of $153 \mathrm{~kg} \cdot \mathrm{ha}^{-1}$ of nitrogen and potassium during the growing season through drip irrigation.

When individuals were $\approx 80 \mathrm{~d}$ old (after seed sowing), they were phenotyped for the presence or absence of trichomes on leaf petioles. Five to 10 petioles were examined per individual. The presence or absence of the maroon spot on flowers was recorded when individuals came into full bloom. To determine the size of the maroon spot, three fully opened flower heads were collected per individual, three ray flowers were pulled off per flower head, and the length of the spot on each ligule (or petal) was measured. The presence or absence of the seed wing was determined with the aid of a magnification glass. 
Table 1. Seeds produced per seed head for each type of cross between Coreopsis leavenworthii (COLE) and Coreopsis tinctoria (COTI) made at the Gulf Coast Research and Education Center, Wimauma, FL, from 2007 to 2008.

\begin{tabular}{lccccc}
\hline & & & \multicolumn{2}{c}{ Seed heads } & \multicolumn{2}{c}{ Seeds (no./seed head) } \\
\cline { 5 - 6 } Cross type & Seed parent & Pollen Parent & examined (no.) & Range & Mean \pm SE \\
\hline Intraspecific & COLE & COLE & 25 & $35.3-66.0$ & $46.4 \pm 5.3 \mathrm{ab}^{z}$ \\
Intraspecific & COTI & COTI & 25 & $13.3-24.0$ & $18.5 \pm 1.9 \mathrm{~cd}$ \\
Interspecific & COLE & COTI & 48 & $1.7-116.0$ & $53.9 \pm 8.0 \mathrm{a}$ \\
Interspecific & COTI & COLE & 48 & $3.0-49.7$ & $27.7 \pm 3.3 \mathrm{bc}$ \\
$\mathrm{F}_{1}$ self & $\mathrm{F}_{1}{ }^{\mathrm{y}}$ & $\mathrm{F}_{1}$ & 21 & $0.3-8.0$ & $2.8 \pm 0.7 \mathrm{~d}$ \\
$\mathrm{~F}_{1}$ sib & $\mathrm{F}_{1}$ & $\mathrm{~F}_{1}$ & 18 & $0.3-43.7$ & $17.8 \pm 6.9 \mathrm{~cd}$ \\
Backcross & $\mathrm{F}_{1}$ & COLE & 24 & $2.0-52.0$ & $18.4 \pm 5.7 \mathrm{~cd}$ \\
\hline
\end{tabular}

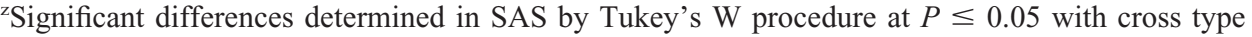
being significantly different with an $\mathrm{F}$ value of 9.91 and $P \leq 0.0001$.

${ }^{\mathrm{y}} \mathrm{F}_{1}$ interspecific hybrids were produce by crossing COLE $\times$ COTI.

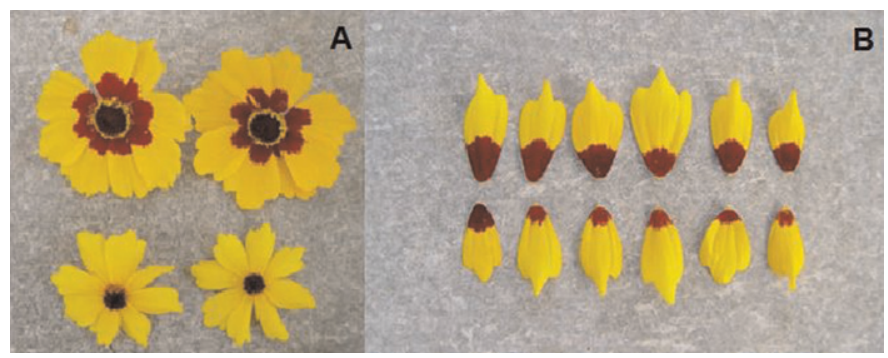

Fig. 1. Morphological characteristic used to detect pollen-mediated gene flow. (A) Maroon spots on Coreopsis tinctoria flowers (top) and absence of the maroon spots on Coreopsis leavenworthii flowers (bottom); and (B) variation in maroon spot size among interspecific hybrids of $C$. tinctoria and $C$. leavenworthii.

DETERMining POLLEN-MEdiated GENE FLOW RATES. A discontinuous design was used with each field block (replicate) consisting of one pollen source plot and nine pollen trap plots. The pollen source plot comprised 16 COTI plants grown at the southern end of the block so that all blocks were planted in the same orientation in the field. The pollen trap plots were 1.5, 3.0, 7.6, 15.2, 30.5, 45.7, 61.0, 76.2, and $91.4 \mathrm{~m}$ away from the pollen source plot, respectively, and each pollen trap plot contained 16 COLE plants. Plants in the pollen source and trap plots were allowed to naturally cross-pollinate by insect pollination under field conditions at the UF-GCREC followed by collecting seeds (or seed heads) from the pollen trap plots, germinating the collected seeds, growing individuals to full bloom, and identifying individuals that expressed the maroon spot of COTI, which would indicate PMGF events. The percentage of such individuals out of the total number of individuals evaluated per plot was calculated as the PMGF rate. Two experiments (Expts. 1 and 2) were conducted over a period of 3 years (2007-2008 and 2008-2009) and in each experiment there were three field blocks (replicates) that were at least $91.4 \mathrm{~m}$ from each other in the east to west direction.

In Expt. 1, COLE and COTI plants were installed in the pollen source or pollen trap plots on 20 Apr. 2007. Soil conditions, ground bed preparation, fumigation treatment, and planting spacing were the same as described previously for the inheritance study. After installation, plants were fertilized with a total of $169 \mathrm{~kg} \cdot \mathrm{ha}^{-1}$ nitrogen, $37 \mathrm{~kg} \cdot \mathrm{ha}^{-1}$ phosphorus, and $210 \mathrm{~kg} \cdot \mathrm{ha}^{-1}$ potassium during the growing season through drip irrigation. Pollen source and pollen trap plants bloomed profusely from the end of May to the end of August. Seed heads were harvested from each of the pollen trap plots on 5 July (Harvest 1 ) and 11 to 14 July 2007 (Harvest 2). In each harvest, 10 seed heads were collected per pollen trap plant, resulting in 160 seed heads per pollen trap plot.

To detect PMGF events, a portion of the seeds harvested from each of the pollen trap plots $(\approx 1000)$ was sowed on 7 Sept. 2007 in a $2.1-\mathrm{L}$ plastic container of soilless medium (Fafard Soil Mix 1P; Conrad Fafard, Anderson, SC) and germinated under mist in a greenhouse at UF, Gainesville, FL. The seedlings were transplanted on 12 Oct. into $80-\mathrm{mL}$ cell trays filled with soilless medium (Fafard Soil Mix 2P; Conrad Fafard) and fertilized with $150 \mathrm{mg} \cdot \mathrm{L}^{-1}$ of $20 \mathrm{~N}-8.7 \mathrm{P}-16.7 \mathrm{~K}$. As the plants bloomed, they were examined for the presence of the maroon spot on flowers. Another portion of the collected seeds $(\approx 1000$ per pollen trap plot) was sowed on 10 and 11 Jan. 2008 at the UF-GCREC. The seedlings were transplanted on 15 and $18 \mathrm{Feb}$. into plastic trays (32 $\mathrm{mL}$ cell volume; Speedling) filled with VCMA and then transplanted to ground beds on 2 Apr. Soil conditions, ground bed preparation, fumigation treatment, plant spacing, irrigation, and fertilization were the same as described previously for the inheritance study. Individuals from each of the pollen trap plots were examined weekly between $14 \mathrm{Feb}$. and 16 July to identify those individuals that expressed the maroon spots on flowers.

In Expt. 2, COLE and COTI plants were installed in the pollen trap or pollen source plots on 26 Mar. 2008. Other growing conditions were the same as those in Expt. 1. Pollen source and pollen trap plants came into full bloom around the end of April. Seed heads were harvested from the pollen trap plants on 28 May and again on 25 June, as described previously.

To detect PMGF events, the collected seeds were sowed on 26 June 2008 (immediately after the second harvest) and germinated under mist. The seedlings were transplanted into 31-mL cell flats (Speedling) on 6 to 8 Aug. and fertilized with $300 \mathrm{mg} \cdot \mathrm{L}^{-1}$ of $20 \mathrm{~N}-8.7 \mathrm{P}-16.7 \mathrm{~K}$ and then transplanted to ground beds on 12 and 15 Sept. All other growing conditions were the same as those used at the UF-GCREC in 2007. Individuals from each of the pollen trap plots were examined weekly between 2 Oct. 2008 and 21 Jan. 2009 to identify those that resulted from PMGF events.

Statistical Analysis. Chi-square analysis was performed to test the goodness of fit of the observed segregation ratios to expected ratios. PMGF rates were fit to a logistic regression curve using PROC GENMOD for the Logistics procedure in SAS (Version 9.3). This procedure has been frequently used to analyze binary responses (as each individual takes one of two possible values).

\section{Results}

\section{Cross-compatibility between $\boldsymbol{C}$. leavenworthii and $\boldsymbol{C}$. tinctoria}

On average COLE $\times$ COTI interspecific crosses produced 53.9 seeds per seed head (Table 1), similar to the number of seeds (46.4) produced per seed head by COLE intraspecific crosses. COTI $\times$ COLE interspecific crosses produced, on 
average, 27.7 seeds per seed head (Table 1), similar to the number of seeds (18.5) produced per seed head by COTI intraspecific crosses. These results indicate that the two species are fully compatible.

On average $F_{1}$ self-pollination produced 2.8 seeds per seed head, $5.2 \%$ and $10.1 \%$ of the seeds produced by the COLE $\times$ COTI and COTI $\times$ COLE interspecific crosses, respectively. The differences between $\mathrm{F}_{1}$ self crosses and the interspecific crosses in seed production were significant. The $\mathrm{F}_{1}$ sib crosses produced 17.8 seeds per seed head (Table 1). Although this is $33.0 \%$ and $64.3 \%$ of the seeds produced by the COLE $\times$ COTI and COTI $\times$ COLE interspecific crosses, respectively, the differences between $\mathrm{F}_{1}$ sib crosses and the interspecific crosses were not statistically significant.

On average the backcrosses produced 18.4 seeds per seed head (Table 1), similar to $F_{1}$ sib crosses. Seed production by backcrosses were $34.5 \%$ and $66.4 \%$ of that by the COLE $\times$ COTI and COTI $\times$ COLE interspecific crosses, respectively, but the differences between the backcrosses and interspecific crosses were not statistically significant.

\section{Inheritance of morphological traits}

Trichomes. Trichomes were present on all $\mathrm{F}_{1}$ individuals evaluated $(\approx 1000)$ from both COLE $\times$ COTI and COTI $\times$ COLE crosses, indicating that the development of trichomes was a dominant trait transferred by COTI. The length and density of trichomes were relatively consistent among leaf petioles of the same plant but varied considerably among $\mathrm{F}_{1}$ individuals, ranging from 2 to $5 \mathrm{~mm}$ and from one or two to as many as 20 trichomes per petiole. All combinations of trichome phenotypes were observed among the evaluated $\mathrm{F}_{1}$ individuals. When individuals had low densities of short trichomes, it became difficult to obtain reliable trichome phenotyping data. Because of this, trichomes were not a reliable morphological marker for tracking PMGF from COTI to COLE.

Maroon spots. Five intraspecific COLE $\times$ COLE crosses resulted in 86 individuals, and they all developed yellow ray flowers without any maroon spots (Table 2). Five intraspecific COTI $\times$ COTI crosses produced 35 individuals, and all individuals expressed the maroon spots on the ray flowers (Table 2). Sixteen COLE $\times$ COTI crosses were made on four COLE (labeled L1 to L4) and four COTI individuals (labeled $\mathrm{T} 1$ to T4) and these crosses resulted in 493 individuals. All of these $F_{1}$ individuals expressed the maroon spot, indicating that the presence of the maroon spot is dominant over non-spotting.
Reciprocal COTI $\times$ COLE crosses produced another $525 \mathrm{~F}_{1}$ individuals, and they all expressed the maroon spot, suggesting that the trait is not maternally inherited but under nuclear gene control.

Selfing seven $F_{1}$ individuals produced only $32 \mathrm{~F}_{2}$ individuals. The maroon spot trait segregated in these individuals, in a 3:1 ratio in each population, with $\chi^{2}=0$ to 1.33 and $P=0.25$ to 1.00 (Table 2), as expected for a single dominant allelecontrolled trait. When the data from the seven $\mathrm{F}_{1}$ families were combined, $25 \mathrm{~F}_{2}$ individuals showed the maroon spot and seven did not. Sib crosses between five $\mathrm{F}_{1}$ individuals produced many more $F_{2}$ individuals (306). The maroon spot trait segregated in a 3:1 ratio in each of the five populations, with $\chi^{2}=0.005$ to 1.45 and $P=0.23$ to 0.94 (Table 2 ). When the data from the five populations were pooled, 227 of these individuals expressed the maroon spot and 79 did not. Backcrossing eight $\mathrm{F}_{1}(\mathrm{COLE} \times$ COTI) individuals with COLE resulted in $370 \mathrm{BC}_{1}$ individuals. Segregation between the presence and absence of the maroon spot individuals in each of the $\mathrm{BC}_{1}$ populations fit a $1: 1$ ratio $\left(\chi^{2}=0.12\right.$ to 2.60 and $P=0.11$ to 0.73$)$. Together 163 individuals expressed the maroon spot and 207 did not.

In summary, results from these $\mathrm{F}_{2}$ and $\mathrm{BC}_{1}$ individuals (a total of 708 individuals) show that the presence of the maroon spot is controlled by a dominant allele at a single locus. We propose to designate this dominant allele in COTI as Spotted (Spt.).

Several hundred additional COTI individuals were examined during the course of this study and all of them expressed the maroon spot, thus suggesting that this gene is very likely to be homozygous in COTI. Being easy to recognize without magnification, homozygous in COTI, and controlled by a single dominant gene, the presence of the maroon spot would serve as a reliable morphological marker to detect PMGF from COTI to COLE.

The four COTI individuals (T1 to T4) used in the mentioned interspecific crosses varied in spot size with the relationship: T3 $>$ $\mathrm{T} 2>\mathrm{T} 1>\mathrm{T} 4$. We analyzed the spot size of $384 \mathrm{~F}_{1}$ individuals (of 493) to determine if this size variation was heritable. When T1, T2, T3, and T4 were used as a maternal parent and crossed with COLE L1, the average maroon spot size in the individuals was $0.38 \mathrm{~cm}(\mathrm{~T} 1 \times \mathrm{L} 1), 0.46(\mathrm{~T} 2 \times \mathrm{L} 1), 0.49(\mathrm{~T} 3 \times \mathrm{L} 1)$, and 0.23 $(\mathrm{T} 4 \times \mathrm{L} 1)($ Fig. $2 \mathrm{~A})$. Similar spot size variations were observed in the crosses of T1, T2, T3, or T4 with L2, L3, or L4 (Figs. 2C, 2E, and $2 \mathrm{G})$, except for the cross $\mathrm{T} 4 \times \mathrm{L} 4$, for which no data were available. When all data were combined and averaged, the spot size in the individuals of T1, T2, T3, and T4 was $0.43 \mathrm{~cm}(120$

Table 2. Segregation of the presence of maroon spots in the individuals of Coreopsis leavenworthii (COLE) and Coreopsis tinctoria (COTI) intraspecific crosses, interspecific $\mathrm{F}_{1}$ and $\mathrm{F}_{2}$, and backcrosses. ${ }^{\mathrm{z}}$

\begin{tabular}{|c|c|c|c|c|c|c|c|c|}
\hline \multirow[b]{2}{*}{ Cross type } & \multirow[b]{2}{*}{ Seed parent } & \multirow{2}{*}{$\begin{array}{l}\text { Pollen } \\
\text { parent }\end{array}$} & \multirow[b]{2}{*}{ Crosses (no.) } & \multicolumn{2}{|c|}{ Individuals (no.) } & \multirow{2}{*}{$\begin{array}{c}\text { Expected } \\
\text { segregation ratio }\end{array}$} & \multicolumn{2}{|c|}{ Chi-square test } \\
\hline & & & & Spotted & Non-spotted & & $\chi^{2}$ value & $P$ value \\
\hline Intraspecific & COLE & COLE & 5 & 0 & 86 & $0: 1$ & 0 & 1 \\
\hline Intraspecific & COTI & COTI & 5 & 35 & 0 & $1: 0$ & 0 & 1 \\
\hline Interspecific $\mathrm{F}_{1}$ & COTI & COLE & 16 & 493 & 0 & $1: 0$ & 0 & 1 \\
\hline Interspecific $\mathrm{F}_{2}$ self & $\mathrm{F}_{1}^{\mathrm{x}}$ & $\mathrm{F}_{1}$ & 7 & 25 & 7 & $3: 1$ & $0-1.33$ & $0.25-1.00$ \\
\hline Interspecific $\mathrm{F}_{2}$ sib & $\mathrm{F}_{1}$ & $\mathrm{~F}_{1}$ & 5 & 227 & 79 & $3: 1$ & $0.01-1.45$ & $0.23-0.94$ \\
\hline
\end{tabular}

${ }^{\mathrm{z}}$ Crosses were made and individuals were grown and examined at the Gulf Coast Research and Education Center in Wimauma, FL, in 2007 to 2008.

${ }^{\mathrm{y}}$ Segregation ratios expected for traits controlled by a single, dominant allele.

${ }^{x}$ Interspecific hybrids were produce by crossing COLE $\times$ COTI. 


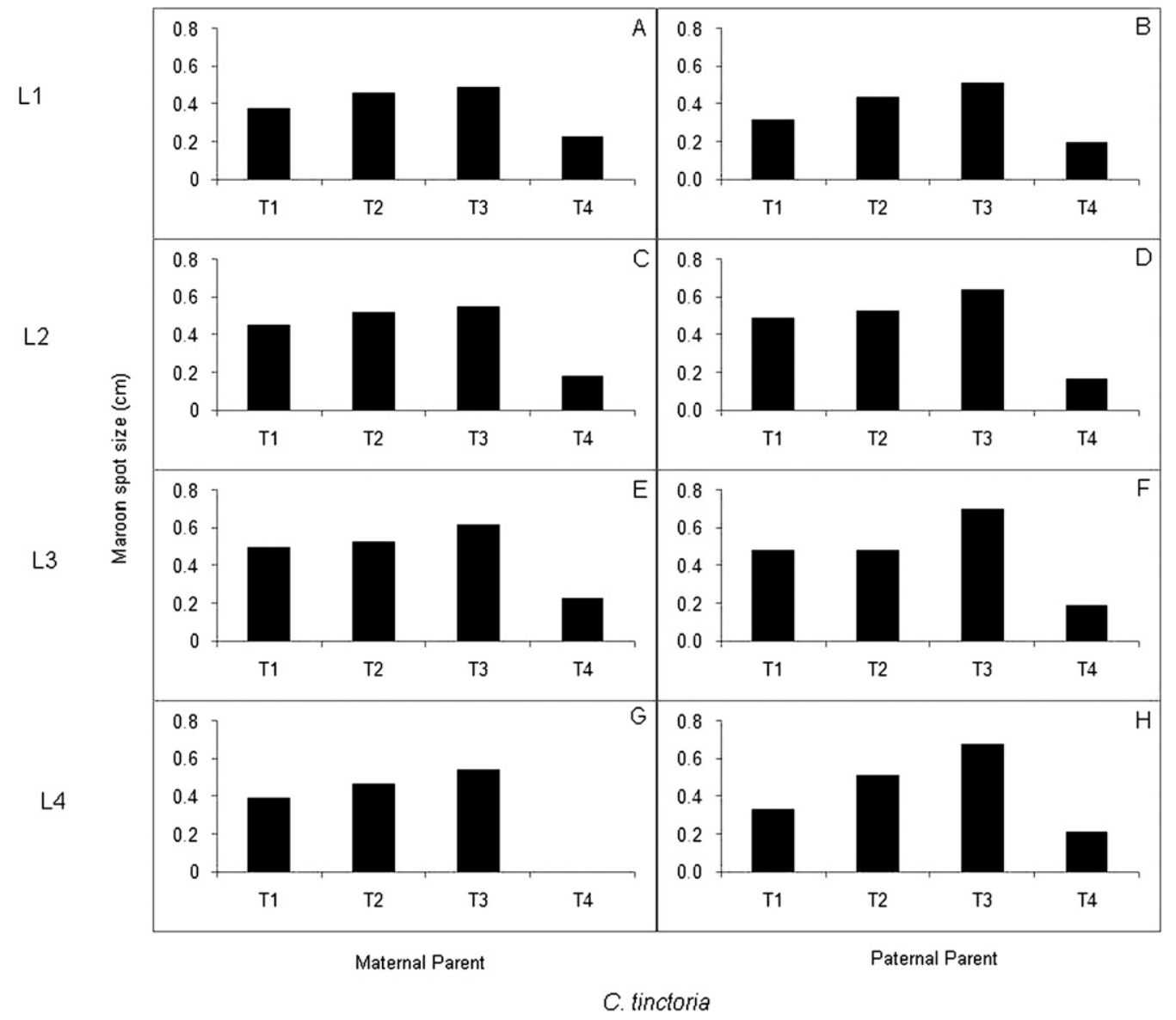

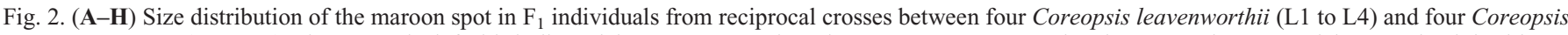
tinctoria parents (T1 to T4). Figures on the left side indicated the maroon spot size when C. tinctoria was used as the maternal parent and those on the right side are when C. tinctoria was used as the paternal parent.

individuals), $0.50 \mathrm{~cm}$ (103 individuals), $0.55 \mathrm{~cm}$ ( 80 individuals), and $0.21 \mathrm{~cm}$ ( 81 individuals), respectively.

To determine if there was any significant maternal effect from COTI on an individual's maroon spot size, reciprocal crosses were made with L1, L2, L3, and L4 individuals as the maternal parent and T1, T2, T3, and T4 individuals as the paternal parent. Approximately 22 individuals per cross were evaluated for spot size. Overall, a similar spot size distribution was observed in the individuals whether T1 to T4 were the maternal or the paternal parent (Fig. 2). For example, with L1 as the maternal parent, the individual's average spot size was $0.32 \mathrm{~cm}$ (T1), $0.44 \mathrm{~cm}$ (T2), $0.51 \mathrm{~cm}$ (T3), and $0.20 \mathrm{~cm}$ (T4) (Fig. 2B), corresponding to the average spot size when T1 to T4 were the maternal parent and L1 was the paternal parent (Fig. 2A). A similar pattern of spot size change was apparent when T1 to T4 were crossed with L2 to L4 (Figs. 2D, 2F, and 2H). In addition, no interactions were detected between COLE individuals and COTI individuals. Thus, the spot size data were combined and averaged. The average maroon spot size of the individuals was $0.41 \mathrm{~cm}$ (T1, 102 individuals), $0.49 \mathrm{~cm}$ (T2, 90 individuals), $0.63 \mathrm{~cm}$ (T3, 89 individuals), and $0.19 \mathrm{~cm}$ (T4, 74 individuals), respectively (Fig. 2). These results suggest that there is not a maternal effect and individual's maroon spot size is dependent on genetic effects from the COTI individuals.

SEed wings. All COLE intraspecific crosses produced winged seeds (5722 seeds evaluated) and all COTI intraspecific crosses produced non-winged seeds (807 seeds evaluated)
(Table 3). In all 40 COLE $\times$ COTI crosses, seeds $(7433$ evaluated) were winged. In 26 COTI $\times$ COLE crosses, seeds were non-winged, but in four other COTI $\times$ COLE crosses, the trait segregated with a ratio of 52 winged seeds: 89 non-winged seed. When $\mathrm{F}_{1}$ individuals were selfed, two crosses produced only winged seeds (23), three crosses produced both winged seeds (48) and non-winged seeds (375), and one cross-produced only non-winged seeds $(100)$. These results seem to indicate heterogeneity and/or complex patterns of inheritance of the trait in COLE. Thus, the trait is not appropriate for tracking PMGF.

\section{Pollen-mediated gene flow from C. tinctoria to C. leavenworthii}

For each pollen trap plot, 581 to 681 individuals were evaluated in Expt. 1 and 593 to 654 individuals were evaluated in Expt. 2 to identify COLE individuals that were expressing COTI's maroon spots. According to the described inheritance study, these individuals would indicate the PMGF from COTI into COLE. The identified individuals were then used to calculate the PMGF rates.

Analysis of variance results indicated that gene flow rates were not significant between the two experiments and among blocks. The highest PMGF rates were observed in the $1.5-\mathrm{m}$ plots at an average of 3.9\% (646 individuals evaluated) in Expt. 1 and 4.2\% (401 individuals evaluated) in Expt. 2 (Fig. 3). As the separation distance increased, the PMGF rates declined rapidly. The farthest separation distance where gene flow was observed was $61.0 \mathrm{~m}$ in Expt. 1 and $15.2 \mathrm{~m}$ in Expt. 2, respectively. At 
Table 3. Segregation of the seed wingedness in crosses of Coreopsis leavenworthii (COLE) and Coreopsis tinctoria (COTI).

\begin{tabular}{lcccrr}
\hline & & & & \multicolumn{2}{c}{ Seeds (no.) } \\
\cline { 3 - 5 } Cross type & Seed parent ${ }^{\mathrm{z}}$ & Pollen parent & Crosses (no.) & Winged & Wingless \\
\hline Intraspecific & COLE & COLE & 40 & 5722 & 0 \\
Intraspecific & COTI & COTI & 30 & 0 & 870 \\
Interspecific & COLE & COTI & 40 & 7433 & 0 \\
Interspecific & COTI & COLE & 26 & 0 & 1989 \\
& & & 4 & 52 & 89 \\
Interspecific $\mathrm{F}_{1}$ & \multirow{2}{*}{$\mathrm{F}_{1}{ }^{\mathrm{y}}$} & $\mathrm{F}_{1}$ & 2 & 23 & 0 \\
& & & 3 & 48 & 375 \\
& & & 1 & 0 & 100
\end{tabular}

${ }^{\mathrm{z}}$ Seeds counted for this study was collected from the seed parent that produced seeds for the cross type listed.

${ }^{\mathrm{y}} \mathrm{F}_{1}$ interspecific hybrids were produce by crossing COLE $\times$ COTI.

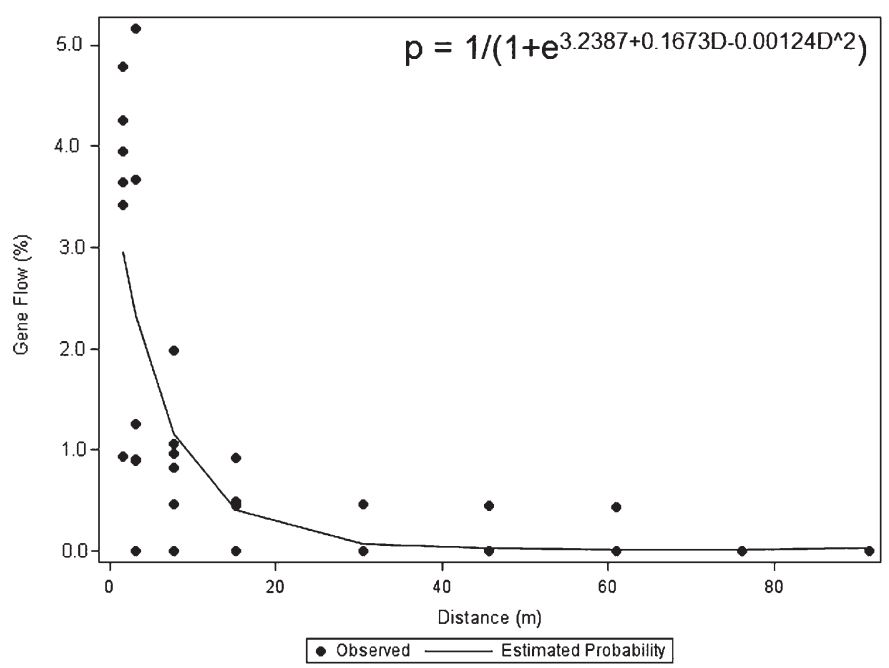

Fig. 3. Scatterplots of observed gene flow rates in Expts. 1 and 2 at each distance measured and logistic regression curve for the equation fitted to the rate of gene flow from Coreopsis tinctoria to Coreopsis leavenworthii at each distance over 2 years.

these distances, the observed gene flow rate was $0.1 \%$ and $0.2 \%$, respectively.

Because the gene flow rates in the two experiments were not significantly different, data were pooled and a regression curve was fit to the observed data using the LOGISTIC procedure in SAS. The best goodness of fit to the observed data was obtained by fitting to the following inverse power law model, $P=1 /\left(1+\mathrm{e}^{3.2387+0.1673 \mathrm{D}-0.00124 \mathrm{D}^{\wedge} 2}\right)$, where $\mathrm{p}$ is the gene flow rate, e the inverse of natural logarithm, and $\mathrm{D}$ the separation distance in meters (Fig. 3). Based on this model, a separation distance of $28 \mathrm{~m}$ and $60 \mathrm{~m}$ would likely lower the gene flow rate from COTI to COLE to $\approx 0.10 \%$ and $0.01 \%$, respectively.

\section{Discussion}

Cross-Compatibility Between C. TINCTORIA AND C. LEAVENWORTHII AND POLLEN-MEDIATED GENE FLOW FROM THE FORMER TO THE LATTER. Among the 13 Coreopsis species in Florida, COTI is in the same section (Calliopsis) with COLE; thus, the two species are most closely related. Previous handpollination studies showed that the two species were crosscompatible and produced $\mathrm{F}_{1}$ hybrids with much reduced pollen stainability (Parker, 1973; Smith, 1976). Our results confirmed the previous findings and further showed that $\mathrm{F}_{1}$ hybrids of COLE and COTI could produce $\mathrm{F}_{2}$ individuals from sib crosses and $\mathrm{BC}_{1}$ individuals when crossed with COLE. These $\mathrm{F}_{2}$ and $\mathrm{BC}_{1}$ individuals appeared to grow normally and produce seeds, indicating that interspecific hybrids of COLE and COTI could sustain beyond the $\mathrm{F}_{1}$ generation. Our results have also shown that COTI could cross-pollinate COLE and form interspecific hybrids with COLE under field conditions when they were grown in close proximity. This suggests that PMGF from COTI can lead to genetic contamination of COLE seeds and compromise the genetic integrity of COLE. Therefore, it will be important to minimize such kind of PMGF during COLE seed production and planting.

Seed production (per seed head) by selfing $\mathrm{F}_{1}$ individuals was $\approx 16.5 \%$ of that by sibbing $\mathrm{F}_{1}$ individuals (2.8 vs. 17.8; Table 1). This large difference is likely the result of the selfincompatibility in the COLE-COTI hybrids. The genus Coreopsis, as well as Asteraceae, is known to be sporophytically self-incompatible (Brewbaker, 1957). A multiple allelic, monogenic system of self-incompatibility has been reported in COTI (Sharma, 1971). A similar system seems to exist in COLE. Hybrids of COLE and COTI are therefore expected to carry a similarly complex self-incompatibility system.

MORPHOLOGICAL MARKERS FOR DETECTING POLLEN-MEDIATED GENE FLOW FROM C. TINCTORIA TO C. LEAVENWORTHI. We observed two morphological characteristics (trichomes on leaf petioles and maroon spots on flowers) that were present in COTI but absent in COLE. Presence of trichomes could be determined in the $\mathrm{F}_{1} \mathrm{~S}$ at the seedling stage and appeared to be a dominant trait, but the expression of this trait varied considerably and segregated in some interspecific $F_{1}$ populations. This kind of variation and segregation was also observed by J.G. Norcini (personal communication). Thus, this trait may allow detecting some, but not all, PMGF from COTI to COLE. Gene flow rates based on such a morphological marker will likely be underestimated. Using the maroon spot as a morphological marker requires growing plants to flowering, which takes additional time and much larger space. Nevertheless, the trait is controlled by a single, dominant allele. Additionally, this character was homozygous in COTI, because no segregation was observed in more than 1000 COTI individuals. With these genetic characteristics, the maroon spot provides a reliable, easy-to-score morphological marker for monitoring and quantifying PMGF from COTI to COLE.

Previously, Smith and Parker (1971) crossed COTI with Coreopsis cardaminefolia (non-spotted) and observed that the maroon spot was expressed in all $\mathrm{F}_{1}$ individuals and segregated among the $\mathrm{F}_{2}$ individuals. However, in their $\mathrm{F}_{2}$ population, only two individuals lacked the maroon spot and 25 individuals expressed the spot. The authors were not able to determine the inheritance of the maroon spot based on the available data. It seems that the reported segregation does not fit a $3: 1$ ratio expected for a single dominant gene-controlled trait $\left(\chi^{2}=4.46\right.$, 
$P=0.03)$. It will remain to be determined whether this deviation is the result of the small size of their $F_{2}$ population or the differences between $C$. cardaminefolia and COLE. Therefore, caution is necessary when using the maroon spot to monitor and quantify PMGF from COTI to other Coreopsis species. It is imperative to know the genetic behavior of the trait in the specific Coreopsis species combinations involved.

There may be occasions where monitoring and quantifying PMGF from COLE to COTI are desired. We observed one trait (seed wings) that was present in COLE but absent in COTI. However, the inheritance of this trait seemed to be rather complex. Smith and Parker (1971) observed a similarly complex pattern of inheritance. When they crossed COTI and $C$. cardaminefolia, all of the $\mathrm{F}_{1}$ individuals produced seeds with partial wings, and the $F_{2}$ individuals produced seeds ranging from non-winged to fully winged (Smith and Parker, 1971). In addition, Parker (1973) had suggested that COTI might have a winged and wingless phase and differed in wingedness depending on the source of the seeds. These factors may make the seed wings unreliable for use in tracking PMGF from COLE to COTI.

Physical SeParation Can Minimize pollen-Mediated gene FLOW FROM C. TINCTORIA TO C. LEAVENWORTHI. Under field conditions, the greatest frequency of PMGF from COTI to COLE occurred at the $1.5-\mathrm{m}$ plot and the gene flow rate consecutively decreased for each plot afterward. The farthest distance that gene flow occurred was $61.0 \mathrm{~m}$ with no gene flow occurring at the 76.2- and 91.4-m plots. The observed PMGF from COTI to COLE follows a leptokurtic curve. Similar patterns of PMGF have been observed in other plant species (Beckie and Hall, 2008; Ellstrand, 1992; Levin, 1981). These results suggest that physical separation can be very effective in minimizing PMGF from COTI and its potential negative impacts to COLE. Based on the leptokurtic model established from the experimental results of this study, a separation distance of $60 \mathrm{~m}$ will likely reduce the PMGF from COTI to COLE to $\approx 0.01 \%$.

\section{Literature Cited}

Beckie, H.J. and L.M. Hall. 2008. Simple to complex: Modeling crop pollen-mediated gene flow. Plant Sci. 175:615-628.

Brewbaker, J.L. 1957. Pollen cytology and self-incompatibility systems in plants. J. Hered. 48:271-277.

Bryant, B. and B.L. Harper-Lore. 1997. Where wildflowers bloom, so does hope. 20 June 2011. <http://www.fhwa.dot.gov/publications/ publicroads/97novdec/p97nov38.cfm>.
Clewell, A.F. 1985. Guide to the vascular plants of the Florida panhandle. University Press of Florida, Tallahassee, FL.

Ellstrand, N.C. 1992. Gene flow by pollen: Implications for plant conservation genetics. Oikos 63:77-86.

Ellstrand, N.C., H.C. Prentice, and J.F. Hancock. 1999. Gene flow and introgression from domesticated plants into their wild relatives. Annu. Rev. Ecol. Syst. 30:539-563.

Havens, K. 1998. The genetics of plant restoration: An overview and a surprise. Restor. Manage. Notes 16:68-72.

Kabat, S.M., J.G. Norcini, and B. Dehgan. 2007. Temperature and light affects germination ecology of commercially produced seed of leavenworth's coreopsis (Coreopsis leavenworthii). Native Plants J. 8:235-247.

Laikre, L., M.K. Schwartz, R.S. Waples, N. Ryman, and The GeM Working Group. 2010. Compromising genetic diversity in the wild: Unmonitored large-scale release of plants and animals. Trends Ecol. Evol. 25:520-529.

Largiadèr, C.R. 2007. Hybridization and introgression between native and alien species. Biol. Invasions 193:275-292.

Levin, D.A. 1981. Dispersal versus gene flow in plants. Ann. Mo. Bot. Gard. 68:233-253.

Markwardt, D. 2005. Texas roadside wildflowers. Native Plants J. 6:69-71.

Parker, H.M. 1973. A biosystematic study of section Calliopsis of Coreopsis (Compositae). PhD diss., Univ. of Arkansas, Little Rock, AR.

Rogers, D.L. 2004. Genetic erosion-No long just an agricultural issue. Native Plants J. 5:112-122.

Rogers, D.L. and A.M. Montalvo. 2004. Genetically appropriate choices for plant materials to maintain biological diversity. Univ. of California. Report to the U.S. Dept. Agr. Forest Serv., Rocky Mountain Region, Lakewood, CO.

Sharma, J.N. 1971. The genetics, nature and occurrence of selfincompatibility and cross-incompatibility in four annual species of Coreopsis L. PhD. diss., Montana State Univ., Bozeman, MT.

Smith, E.B. 1976. A biosystematic survey of Coreopsis in eastern United States and Canada. SIDA Contrib. Bot. 6:123-215.

Smith, E.B. and H.M. Parker. 1971. A biosystematic study of Coreopsis tinctoria and C. cardaminefolia (Compositae). Brittonia 23:161-170.

Texas Department of Transportation. 2011. Wildflower facts. 20 June 2011. <http://www.txdot.gov/public_involvement/wildflowers/ facts.htm>.

U.S. Department of Agriculture. 2011. Plants database. 7 July 2011. $<$ http://plants.usda.gov/java/nameSearch?keywordquery=coreopsis + leavenworthii\&mode $=$ sciname \&submit. $x=0 \&$ submit. $y=0>$.

Wunderlin, R.P. 1998. Guide to the vascular plants of Florida. University Press of Florida, Gainesville, FL.

Wunderlin, R.P. and B.F. Hansen. 2004. Atlas of Florida vascular plants. 7 May 2011. <http://www.plantsatlas.usf.edu>. 